\title{
A new marrellid arthropod from the Ordovician of Wales
}

\author{
David A. Legg \\ Acta Palaeontologica Polonica 61 (3), 2016: 617-619 doi:http://dx.doi.org/10.4202/app.00246.2016
}

A new taxon of marrellid marrellomorph Dyrnwynia conollyi gen. et sp. nov. is described

from the Middle Ordovician (middle Darriwilian, Didymograptus artus Biozone) Llanfallteg Formation of Northern Pembrokeshire, Wales, UK. This taxon, represented by a single specimen, is characterised by the possession of mediolateral spines with tightly spaced secondary cephalic spines limited to their external margins and that decrease in size towards the distal tip. This is the first record of marrellid arthropods from Great Britain and only the fourth record from the entire Ordovician worldwide, which, given their current geographic and temporal distribution, indicates that marrellid arthropods may be more common in the fossil record than previously recognised.

David A. Legg [david.legg@oum.ox.ac.uk], Oxford University Museum of Natural History, Parks Road, Oxford OX1 3PW, UK.

This is an open-access article distributed under the terms of the Creative Commons Attribution License (for details please see creativecommons.org), which permits unrestricted use, distribution, and reproduction in any medium, provided the original author and source are credited.

For 2 Full text $(210.6 \mathrm{kB})$ 